\title{
THE
}

\section{Lactate Dehydrogenase Like Crystallin: A Potentially Protective Shield for Indian Spiny-Tailed Lizard (Uromastyx hardwickii) Lens Against Environmental Stress?}

\author{
Ambreen Atta \\ Amber llyas \\ Zehra Hashim \\ Aftab Ahmed \\ University of Rhode Island \\ Shamshad Zarina \\ Follow this and additional works at: https://digitalcommons.uri.edu/bps_facpubs
}

The University of Rhode Island Faculty have made this article openly available.

Please let us know how Open Access to this research benefits you.

This is a pre-publication author manuscript of the final, published article.

Terms of Use

This article is made available under the terms and conditions applicable towards Open Access Policy Articles, as set forth in our Terms of Use.

\section{Citation/Publisher Attribution}

Atta, A., Ilyas, A., Hashim, Z., Ahmed, A., \& Zarina, S. (2014). Lactate dehydrogenase like crystallin: A potentially protective shield for Indian spiny-tailed lizard (Uromastyx hardwickii) lens against environmental stress? The Protein Journal, 33(2), 128-34. http://dx.doi.org/10.1007/s10930-014-9543-4 Available at: http://dx.doi.org/10.1007/s10930-014-9543-4

This Article is brought to you for free and open access by the Biomedical and Pharmaceutical Sciences at DigitalCommons@URI. It has been accepted for inclusion in Biomedical and Pharmaceutical Sciences Faculty Publications by an authorized administrator of DigitalCommons@URI. For more information, please contact digitalcommons-group@uri.edu. 
Lactate dehydrogenase like crystallin: a potentially protective shield for Indian spiny-tailed lizard (Uromastix hardwickii) lens against environmental stress?

Ambreen Atta ${ }^{a}$, Amber Ilyas, Zehra Hashima, Aftab Ahmed ${ }^{\mathrm{a}}$ and Shamshad Zarina $^{\mathrm{a}, *}$

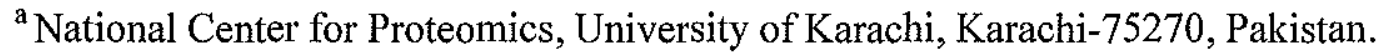

${ }^{b}$ Biomedical and Pharmaceutical Sciences, University of Rhode Island, Kingston, Rhode Island 02881, USA.

*To whom correspondence should be addressed

National Center for Proteomics, University of Karachi, Karachi-75270, Pakistan Email: szarina@uok.edu.pk

Tel. no: 00-92-21-34656511

Fax no: 00-92-21-34650726 


\section{Abstract:}

Taxon specific lens crystallins in vertebrates are either similar or identical with various metabolic enzymes. These bifunctional crystallins serve as structural protein in lens along with their catalytic role. In the present study, we have partially purified and characterized lens crystallin from Indian spiny-tailed lizard (Uromastix hardwickii). We have found lactate dehydrogenase (LDH) activity in lens indicating presence of an enzyme crystallin with dual functions. Taxon specific lens crystallins are product of gene sharing or gene duplication phenomenon where a pre-existing enzyme is recruited as lens crystallin in addition to structural role. In lens, same gene adopts refractive role in lens without modification or loss of pre-existing function during gene sharing phenomenon. Apart from conventional role of structural protein, LDH activity containing crystallin in Uromastix hardwickii lens is likely to have adaptive characteristics to offer protection against toxic effects of oxidative stress and ultraviolet light, hence justifying its recruitment. Taxon specific crystallins may serve as good models to understand structure-function relationship of these proteins.

\section{Key words:}

$\varepsilon$-crystallin, gene recruitment, gene sharing, lactate dehydrogenase, reptilian lens, taxon specific crystallin.

\section{Abbreviations}

LDH Lactatedehydrogenase

PVDF Polyvinylidene difluoride

RP-HPLC Reverse phase -High performance liquid chromatography 
UV Ultra-violet.

\section{Introduction:}

Lenses of vertebrate eyes play vital part in maintaining transparency and refractive index [1]. Main component of lenses are structural proteins, called crystallins. Due to their unique properties, role in transparency, evolutionary history and distribution patterns, crystallins have been subject of interest since decades. They are mainly classified into two groups, namely ubiquitous crystallins and Enzyme or taxon specific crystallins. First group contains $\alpha, \beta$ and $\gamma$ crystallins which are most prevalent in vertebrate and invertebrate lenses while latter includes taxon specific crystallins which are identical or closely related with metabolic enzymes prevalent in scattered group of species [2]. Taxon specific crystallins were first observed in birds followed by discovery in lenses of other species [3]. These crystallins are shown to be either the product of gene sharing [4] or gene duplication phenomenon [5]. During gene sharing phenomenon, same gene adopts refractive role in lens without modification/loss of pre-existing function [4]. The $\tau$-crystallins of Crocodylus palustris is an example of gene sharing phenomenon containing sequence similarity with $\alpha$-enolase from brain, heart, and gonad [6]. In gene duplication, however, original gene is duplicated to produce two copies of gene among which one copy retains its original catalytic activity while other become structural protein in lens [5]. In avian lens, argininosuccinate lyase gene is duplicated; one copy of gene maintained its role as enzymes ( 82 -crystallin), while 
other gene has evolved as structural protein by losing little or all catalytic activity [3].

A major protein component in birds and reptiles is $\varepsilon$ crystallin which is homologous to glycolytic enzyme lactate dehydrogenase (LDH) [7, 8]. Lactate dehydrogenase is responsible for converting glucose to lactate during anaerobic condition [9], subsequently, forming ATP. LDH has various isozymes which are tissues specific; such as LDH-A and LDH-B are found in muscle and heart, respectively. During evolution, the distribution of LDH isozymes has varied in different organs but function remained same [10]. Scientists suggested that distribution of LDH isozymes in different organs might be due to gene duplication or gene sharing phenomenon under selective pressures [1]. Birds and reptiles have diverged almost 200 million years ago and still share some morphological characters; however, difference in their proteins composition has been observed $[11,12]$. Staple et al. [8] have reported presence of $\varepsilon$-crystallin in many avian lenses. In case of reptiles, evidence for $\varepsilon$-crystallin existence was found only in caiman, crocodiles and alligator which belong to order crocodylus. So far, there is only one report for presence of $\varepsilon$-crystallin in gecko phelsuma, a member of order squamata [13].

In this study, Uromastix hardwickii was used as an experimental model. Uromastix hardwickii belongs to reptilian family, order squamata, and has certain unique characteristics of amphibians, birds and mammals [14]. It is a terrestrial, hibernating, burrowing and diurnal animal commonly found in desert. Due to 
diversified environment Uromastix hardwickii lives in, it is a model animal to understand the gene recruitment phenomenon and biochemical adaptations. The lens crystallins of Uromastix hardwickii has not been studied so far. In the present investigation, partial purification and characterization of $\varepsilon$-crystallin was performed using chromatographic techniques including gel filtration, RP-HPLC and affinity chromatography. Furthermore, e-crystallin/LDH gene expression and DNA sequencing studies were also conducted.

\section{Materials and Methods:}

\section{Sample collection and protein extraction:}

The study was conducted after approval of Institutional Review Board, University of Karachi. All research procedures followed were in accordance with the standards set forth in the Guide for the Care and Use of Laboratory Animals (National Academy of Science, National Academy Press, Washington, D.C.). Fresh lenses from Uromastix hardwickii were removed and homogenized in $50 \mathrm{mM}$ sodium phosphate buffer, $\mathrm{pH} 7.0$ on ice in a ratio of $1 / 10(\mathrm{w} / \mathrm{v})$. Homogenate was

centrifuged at $15,000 \times \mathrm{g}$ for $20 \mathrm{~min}$ at $4^{\circ} \mathrm{C}$. The supernatant was collected and labeled as water soluble fraction. The protein concentration was determined by Bradford protein assay kit (BioRad).

\subsection{Protein purification:}


Gel filtration chromatography was performed for the separation of lens proteins. $100 \mathrm{mg}$ protein was loaded on Sephacryl S-300 gel filtration column $(90 \times 2.5 \mathrm{~cm})$ and eluted at room temperature with $0.01 \mathrm{M}$ phosphate buffer saline $(\mathrm{pH}$ 7.4). Fractions were collected at the flow rate of $12-15 \mathrm{ml} / \mathrm{hr}$. Both crude water soluble lens proteins and peak-2 from gel filtration chromatography were fractionated by RP-HPLC (Perkin Elmer USA). $150 \mu 1$ sample was injected to RP C18 (25x46mm) column equilibrated with $0.1 \%$ Trifluoroacetic acid (solvent A). Proteins were eluted using a gradient of solvent $\mathrm{A}$ and solvent $\mathrm{B}$ (Acetonitrile containing $0.1 \%$ Trifluoroacetic acid) attaining $70 \% \mathrm{~B}$ in 40 minutes. Elution was monitored at 280 $\mathrm{nm}$. Affinity chromatography was also employed to separate proteins from gel filtration chromatography peak-2 and crude lens protein extract. Fresh lenses (5) were homogenized in $20 \mathrm{mM}$ Tris- $\mathrm{HCl}$ buffer, $\mathrm{pH} 8.0$ (equilibration buffer) and centrifuged at $15,000 \times \mathrm{g}$ for $20 \mathrm{~min}$ at $4{ }^{\circ} \mathrm{C}$. Approximately $7.2 \mathrm{mg}$ protein from water soluble fraction in equilibration buffer was applied on gel affinity column $(10 \times 1.5 \mathrm{~cm})$ packed with Affi-gel Blue (BioRad). After elution of unbound fractions in equilibration buffer, bound proteins were eluted with same buffer containing $1 \mathrm{M} \mathrm{NaCl}$. Same procedure was used for affinity purification of catalytically active gel filtration fraction (peak-2) after an overnight dialysis in equilibration buffer at $4{ }^{\circ} \mathrm{C}$.

\subsection{Measurement of enzymatic activity:}

Lactate dehydrogenase activity was determined in water soluble fraction, individual peaks of gel filtration chromatography and affinity chromatography purified fractions 
using Randox Ld pyruvate lactate assay kit (Cat no. LD 401). The activity was determined by monitoring the decrease in absorbance at $340 \mathrm{~nm}$ for $3 \min$ [15].

\subsection{SDS-PAGE:}

Sodium dodecyl sulphate polyacrylamide gel electrophoresis (SDS-PAGE) was performed according to the procedure of Laemmli [16] using $12 \%(\mathrm{w} / \mathrm{v})$ resolving gel. Protein bands were stained using $0.2 \%$ coomassie brilliant blue (CBB) R-250 and were visualized using PD Quest software (BioRad).

\section{$2.5 \mathrm{~N}$-terminal sequencing:}

Partially purified protein fraction of affinity chromatography was subjected to SDSPAGE and electroblotted onto a PVDF membrane. The bands were excised and analyzed for N-terminal amino acid sequencing using a Procise automated protein sequencer (Applied Biosystems, Inc).

\section{6 nLC-MS/MS analysis:}

Bands from SDS-PAGE gel of partially purified affinity chromatography fraction (Fig. 5) excised and digested with trypsin. The tryptic peptides were subjected to analysis using Thermo LTQ XL linear ion trap mass spectrometer interfaced with nano-LC system. Sample $(1 \mu \mathrm{L})$ was injected through an auto-sampler into the $\mathrm{nLC}$ system. The column (75 $\mu \mathrm{m}$ I.D x15 cm Pep-Map $100 \mathrm{C}-18$ nano column) was equilibrated with $96.8 \% \mathrm{~A}(0.1 \%$ Formic acid) and 3.2\% B (98\% Acetonitrile, $2 \%$ water, $0.1 \%$ Formic acid). Peptide separation was achieved with multi-step gradient from $3.2 \%$ to $80 \%$ solution $\mathrm{B}$ at the flow rate of $300 \mathrm{~nL} / \mathrm{min}$ over $70 \mathrm{~min}$. Mass 
spectra of nLC-MS/MS data were analyzed for protein identification using Mascot search engine against NCBInr (www.ncbi.nlm.nih.gov/RefSeq/).

\subsection{Gene expression analysis:}

Total RNA was extracted from Uromastix hardwickii lenses by using SV total RNA isolation system kit (Promega, USA) according to manufacturer's protocol. Total RNA was reverse transcribed into cDNA by using reverse transcription kit (Invitrogen, UK). PCR amplification of total lens cDNA was performed by using GoTaq® Green Master Mix (2X) (Promega, U.S.A). Each $25 \mu$ l reaction volume

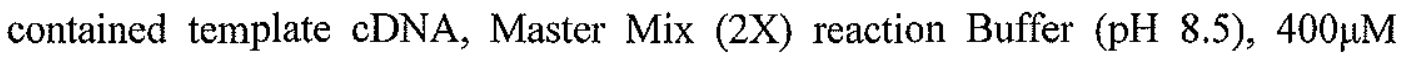
dNTPs and $3 \mathrm{mM} \mathrm{MgCl} 2$ with sense (5'GGGACTGACCAAGATCCAGA3 ${ }^{`}$ ) and antisense (5' CCCTTGACCATGGTGGATAC $3^{\prime}$ ) primers of $L D H$ gene. PCR blank and RT- blank were used as negative control. Annealing temperatures (Tm) of both reverse and forward primers was $62.4^{\circ} \mathrm{C}$ and expected gene product size was $180 \mathrm{bp}$.

\subsection{Agarose gel electrophoresis:}

PCR product was visualized by using agarose gel electrophoresis. Agarose (2\%) gel was prepared in TBE buffer (45mM Tris, $45 \mathrm{mM}$ Boric acid, $1 \mathrm{mM}$ EDTA) pH 8.5. Agarose was heated in TBE buffer until solution became clear. $0.5 \mu \mathrm{g} / \mathrm{ml}$ ethidium bromide was added in warm agarose solution. After agarose gel solidification, PCR products $(12 \mu \mathrm{l})$ were loaded in wells. TBE buffer was used as running buffer at $80 \mathrm{~mA}$ for $40 \mathrm{~min}$. DNA ladder (100 bp) was used as marker. 
The DNA bands were visualized under UV light using gel documentation system (BiomRad).

\subsection{DNA Sequencing:}

PCR products were directly used for DNA sequencing analysis using DNA sequencing system 3130 (Applied Biosystem, U.S.A.). DNA sequencing reactions was carried out by Big-dye Terminator Cycle sequencing kit. Analysis of DNA sequences was done by using basic logical alignment search tool BLAST (www.ncbi.nlm.nih.gov/blast). Multiple sequence alignment was constructed using CLUSTALW (www.genome.jp/tools/clustalw/).

\section{Results:}

Total protein content determined by Bradford protein assay from water soluble fraction was found to be $1.5 \mathrm{mg} / \mathrm{lens}$. Elution profile of crude lens homogenate from Uromastix hardwickii on Sephacryl S-300 column is presented in Fig. 1. Total lens homogenate was fractionated into five peaks which were all examined for LDH activity. Only peak-2 was found to be catalytically active (37.14 U/L). SDS-PAGE of peak-2 revealed more than one protein bands is shown in Fig. 2. Elution profile of total lens homogenate and rechromatography of peak-2 from Sephacryl S-300 by reverse phase HPLC is depicted in Fig.3. Peak-2 rechromatography yielded a peak which was subjected to nLC-MS/MS analysis which revealed a match with $\gamma$ s crystallin from Iguana iguana (Ac. No: AAV54036) with $7 \%$ coverage. Affi-gel purified fraction had an activity of 
284.76 U/L LDH (Fig. 4). SDS-PAGE analysis of affi-gel fraction revealed two bands of $22 \mathrm{kDa}$ and $14 \mathrm{kDa}$ which showed $22 \%$ and $20 \%$ band density, respectively (Fig. 5).

$\mathrm{N}$-terminal sequencing analysis of $22 \mathrm{kDa}$ protein band resulted in sequence of 9 residues. BLASTp analysis of observed sequence identified $22 \mathrm{kDa}$ band to be truncated $\beta A 2$-crystallin (Fig. 6). Second protein band of $14 \mathrm{kDa}$, however, gave no results. Both bands were also subjected to nLC-MS/MS analysis. Resulted peptides matched ( $26 \%$ coverage) with $\beta A 2$-crystallin of Iguana iguana having a molecular weight of $22.4 \mathrm{kDa}$ (Ac. No: AAN78174), thus confirming 22kDa band to be $\beta A 2$-crystallin. The second band revealed a match with $\gamma \mathrm{s}$-crystallin from Iguana iguana (Ac. No: AAV54036) with 6\% coverage.

Gene expression from lens and liver using $\varepsilon$-crystallin/LDH primers is shown in Fig. 7. $L D H$ expression was found to be higher in liver as compared to the lens. DNA sequencing of PCR product showed nucleotide sequence of $119 \mathrm{bp}$ corresponding to 39 amino acids (Fig. 8). Alignment of resulting nucleotides with selected sequences is shown in Fig. 9.

\section{Discussion:}

Taxon specific crystallins have been a subject of interest to study gene recruitment phenomenon in many organisms. Apart from being abundant, the taxon specific lens crystallins have retained catalytic function along with structural role in lens [4]. The

rationale for recruitment of different enzymes as lens crystallins is still unclear. The 
requirement of catalytic activity is unlikely to be the reason for the presence of high concentrations of enzyme crystallin in lens as, in few cases; enzyme crystallins have lost their catalytic role either due to post-translational modification or due to gene duplication phenomenon [5]. The gene coding for recruited enzyme is likely to be exposed to different selective pressures during the process of evolution in order to retain catalytic activity along with high expression to maintain transparency and proper refractive properties of the lens [17]. Such environmental pressures and adaptive conflict in animals is helpful in understanding the structure-function relationship of crystallins as species move from water to land, ground to air and from dark to light [18].

Among many enzyme crystallins identified so far, $\varepsilon$-crystallin has shown limited distribution restricted to avian and crocodilian species. It is already established that $\varepsilon$-crystallin have sequence similarity with $\mathrm{LDH}$ enzyme. $\varepsilon$-crystallin was first identified in duck lenses where it was one tenth of the total protein [8]. Later, it was explored in many members of avian family. In reptilian family, however, the presence was reported in members of order crocodylus including alligators, caiman and crocodiles while in case of order squamata, only one member (gecko phelsuma) [13], has shown presence of $\varepsilon$-crystallin. In present investigation, we have partially purified and identified $\varepsilon$-crystallin from lens of Uromastix hardwickii (order squamata). We have used gel filtration and RP-HPLC for the separation of \&crystallin/LDH. Gel filtration separation resulted in five peaks of which, fraction 2 showed LDH activity. RP-HPLC fractionation of crude water soluble lens crystallins showed one fraction with enzymatic activity. Affinity chromatography 
using Affi Gel Blue was then used for further purification of $\varepsilon$-crystallin/LDH. Affi-Gel blue gel has been used for the final step purification of dinucleotide fold containing enzymes such as lactate dehydrogenase enzyme [19] and phosphofructokinase enzymes [20]. SDS-PAGE analysis of affinity eluted fraction (fig 5), revealed two bands of 22 and $14 \mathrm{kDa}$. $\mathrm{N}$-terminal analysis identified 22 $\mathrm{kDa}$ protein band as truncated $\beta \mathrm{A} 2$-crystallin. $\beta$-crystallin are oligomeric proteins with blocked $\mathrm{N}$-terminal. However, presence of truncated $\beta$-crystallins has also been reported. $\beta$-crystallin has co-eluted with $14 \mathrm{kDa}$ protein during affinity purification. This interaction in not surprising since similar interaction has been observed in rabbit lenses between $\beta$ and $\lambda$-crystallin [21]. Another study reported interaction among $\alpha \mathrm{A}$-crystallin and $\delta$-crystallin [22]. $\beta \mathrm{A} 2$-crystallin from Uromastix hardwickii showed maximum similarity (98\% homology) in nine residues with Iguanu iguana $\beta A 2$-crystallin, consisting of 189 residues long protein. Efforts to identify $14 \mathrm{kDa}$ protein band by $\mathrm{N}$-terminal sequence analysis were unsuccessful, most likely due to blocked N-terminal. MS analysis, however, identified this band to be $\gamma \mathrm{s}$ crystallin. Affi gel eluted fraction showed high LDH activity $(284.76 \mathrm{U} / \mathrm{L})$ but we could only identify $\beta \mathrm{A} 2$ and $\gamma \mathrm{s}$ crystallin from this fraction. We were able to confirm the presence of $\varepsilon$-crystallin/LDH expression at mRNA level in lens. Sequence alignment of $\varepsilon$-crystallin/LDH showed I. iguana and S. undulates (Fig. 9) demonstrate $40 \%, 51 \%$ alignment score respectively. The region containing 23 nucleotides is highly conserved in Uromastix hardwickii, Iguana iguana and Sceloporus undulates. Partial sequence of Uromastix hardwickii showed more sequence similarity with Sceloporus undulates than Iguana iguana. 
It is interesting to note that recruited enzymes are mostly derived from oxidoreductases and dehydrogenases which require NADH or NADPH as cofactors. Lenses of certain species contain high content of these nucleotides suggesting active redox cycle in vivo [23]. Due to high reducing nucleotide (NADH/NADPH) binding capability, these enzyme crystallins not only help to keep up the redox balance against oxidative stress but are also beneficial as near UV filters [24]. Reduced form of NAD absorbs strongly in near ultra violet region, hence presence of $\varepsilon$-crystallin in birds and crocodiles is likely to provide protection against UV glare to facilitate prey hunting [25]. Since Uromastix harwickii lives in desert and has maximum UV exposure [14], presence of LDH like crystallin may act as protective shield against oxidative stress and UV radiation. Thus, presence of enzyme crystallin may be regarded as defense mechanism against environmental stress.

Uromastix hardwickii is burrowing and hibernating animal and lives in desert. During day time, they accommodate in digger burrows in order to avoid ultra violet light exposure [14] while in hibernation period during winter; they hide under ground for six months without eating and drinking. Metabolic activities are continued in all situations for their survival, and energy generation process entirely depends on anaerobic glycolysis [26]. During anaerobic condition, lactate dehydrogenase expression in different tissues is very high indicating the role in fulfilling energy requirement. High lactate dehydrogenase expression might be the biochemical adaptation to compensate partially low temperature and anaerobic 
condition in nocturnal lizards [27]. In eye lens, however, presence of catalytic activity is still questionable.

The recruitment of enzyme crystallins demonstrates a model of molecular evolution in which changes occur before or instead of gene duplication. $\varepsilon$-crystallin is a product of recruitment of a pre-existing enzyme to structural role during which the protein retains its catalytic role outside lens. $\varepsilon$-crystallin represents an example of gene sharing phenomenon as two distinct phenotypes have been produced. The bi-functional enzyme crystallin has thus acquired a new role by modification of gene expression during the process of evolution. Further investigations are required to evaluate various characteristics of recruited metabolic enzyme as the process may have wide implication in protein evolution and differential gene expression mechanism.

\section{Acknowledgements:}

DNA sequencing analysis and $\mathrm{N}$-terminal protein sequencing were provided by Centralized Science Laboratory, University of Karachi, Pakistan and RI-INBRE Centralized Core Facility, University of Rhode Island, USA, supported by grant \#

5P20GM103430-13 from the National Institute of General Medical Sciences of the National Institute of Health.

\section{References:}

1- Bloemendal H (1981) In: Bloemendal H (ed) Molecular and cellular biology of the eye lens, John Wiley and Sons, New York 
2- Wistow G, Piatigosky J (1988) Lens crystallins evolution and expression of proteins for a highly specialized tissue. Ann Rev Biochem 57: 479-504

3- Barbosa P, Wistow GJ, Cialkowski M, Piatigorsky J, O'brien WE (1991) Expression of duck lens delta-crystallin cDNAs in yeast and bacterial hosts. Delta 2-crystallin is an active argininosuccinate lyase. J Biol Chem 266 (33): 22319-22

4- Wistow G, Richardson J, Jaworski C, Graham C, Sharon-Friling R, Segovia L (1994) Crystallins: The over expression of Functional Enzymes and stress proteins in the eye lens. Biotechnol Genet Eng Rev 12: 1-38

5- Piatigorsky J, Wistow G (1991) The recruitment of crystallins: New function precedes gene duplication. Science 252: 1078-1079

6- Agrawal R, Chandrashekhar R, Mishra AK, Ramadevi J, Sharma Y, Aggarwal RK (2002) Cloning and sequencing of complete tau-crystallin cDNA from embryonic lens of Crocodylus palustris. J Biosci 27 (3): 251-9

7- Piatigorsky J (1992) Lens crystallins. Innovation associated with changes in gene regulation. J Biol Chem 267(7): 4277-80

8- Stapel SO, Zweers A, Dodemont HJ, Kan JH, De Jong WW (1985) epsilonCrystallin, a novel avian and reptilian eye lens protein. Eur J Biochem 147(1): 12936

9- Metzler DE (1977) In Biochemistry: The chemical reactions of living cells, Academic Press, New York

10- Cahn RD, Kaplan NO, Zwilling E, Levine L (1962) Nature and Development of Lactic Dehydrogenases: The two major types of this enzyme form molecular hybrids which change in makeup during development. Science 136: 962-969 
11- Keeton WT (1972) In: Biological science, 2nd edn, W. W. Norton, New York.

12- De Jong WW, Stapel SO, Zweers A (1981) \&-Crystallin, a novel avian and reptilian eye lens protein. Comp Biochem Physiol 69: 593-598

13- Roll B, Amons R, De Jong, WW (1996) Vitamin $A_{2}$ Bound to Cellular Retinolbinding Protein as Ultraviolet Filter in the Eye Lens of the Gecko Lygodactylus picturatus. J Biol Chem 271: 10437-10440

14- Zain-Ul-Abedin M, Barbara KZ (1977) In: Characterization, Biochemistry of the Lizard Uromastix hardwickii, University of Karachi, Pakistan

15- Weisshaar HD, Prasad MC, Parker RS (1975) Estimation of Lactate Dehydrogenase in serum/plasma. Med Welt, 26: 387-391

16- Laemmli UK (1970) Cleavage of structural proteins during assembly of the head of bacteriophage. Nature 227: 680-685

17- Piatigorsky J (1993) Puzzle of Crystallin Diversity in Eye Lenses. Developmental dynamics 196: 267-272

18- Wistow G, Wyatt K, David L, Gao C, Bateman O, Bernstein S, Tomarev S, Segovia L, Slingsby C, Vihtelic T (2005) Gamma N-crystallin and evolution of the beta gamma-crystallin super family in vertebrates. FEBS J 272(9): 2276-91

19- Ryan LD, Vestling CS (1974) Rapid purification of lactate dehydrogenase from rat liver and hepatoma: a new approach. Arch. Biochem Biophys 160(1): 279-84

20- Kopperschlager G, Diezel W, Freyer R, Liebe S, Hofmann E (1971) Reciprocity of yeast-phosphofructokinase with dextran blue 2000. Eur J Biochem 22(1): 40-5 
21- Akatsuka I, Bando M, Obazawa H, Oka M, Takehana M and Kobayashi S (2001) NADH-dependent Dehydroascorbate Reductase in the Rabbit Lens. Tokai J Exp Clin Med 26: 25-32

22- Ya-Huei C, Ming-Ting L, Yu-Wen C, Wei-Yuan C, Chung-Ming Y, Hwei-Jen L (2011) Distinct interactions of $\alpha \mathrm{A}$-crystallin with homologous substrate proteins, $\delta$ crystallin and argininosuccinate lyase, under thermal stress. Biochimie 93:314-320

23- Zigler Jr JS, Rao PV (1991) Enzyme/crystallins and extremely high pyridine nucleotide levels in the eye lens. FASEB J 5: 223-225

24- Wistow G (1995) In: Molecular biology and evolution of crystallins: gene recruitment and multifunctional proteins in eye lens. RG Landes, U.S.A.

25- Wistow G, Mulders JWM, de Jong WW (1987) The enzyme lactate dehydrogenase as a structural protein in avian and crocodile lens. Nature 326: 622-624

26- Lehringer-Albert L, Nelson-David L, Cox-Michael M (1993) Principles of Biochemistry, 2nd edn, Worth Publisher, New York

27- Bennett AF, Dawson WR (1976) In: Gans C, Dawson WR (Eds) Biology of reptilian-physiology, 4th edn. Academic press, England

\section{Legends:}

Fig1: Elution profile of Uromastix hardwickii eye lens extract from Sephacryl S300 column $(90 \times 2.5 \mathrm{~cm})$. Approximately $100 \mathrm{mg}$ proteins were eluted using $0.01 \mathrm{M}$ phosphate buffer saline $(\mathrm{pH} \mathrm{7.4)}$ at room temperature and $3 \mathrm{ml}$ fractions were collected. Solid line indicates protein concentration monitored at $280 \mathrm{~nm}$ while dotted line indicates LDH activity. 
Fig 2: SDS-PAGE analysis of different fractions obtained from gel filtration chromatography. In each well, $30 \mu \mathrm{g}$ protein was loaded. $\mathrm{C}=$ crude water soluble proteins, Lane 1-5= gel filtration peaks, $\mathrm{M}=$ molecular weight marker.

Fig 3: RP-HPLC separation profile of crude lens homogenate (solid line) and peak2 from Sephacryl S-300 fractionation (dashed line). Sample ( $\sim \mathrm{mg}$ ) was separated using a gradient of $0.1 \%$ Trifluoroacetic acid (solvent $\mathrm{A}$ ) and solvent $\mathrm{B}$ (Acetonitrile containing 0.1\% Trifluoroacetic acid) in 40 minutes $(70 \% \mathrm{~B})$.

Fig 4: LDH activity of Affi-Gel blue gel purified peak-2 from Sephacryl S-300 fractionation. Sold line indicates absorbance at $280 \mathrm{~nm}$ while dashed line indicates LDH activity. Water soluble fraction $(\sim 7.2 \mathrm{mg})$ was equilibrated in equilibration buffer (20 mM Tris- $\mathrm{HCl}$ buffer, $\mathrm{pH} 8.0$ ) while bound protein was eluted with equilibration buffer containing $1 \mathrm{M} \mathrm{NaCl}$.

Fig 5: SDS-PAGE profile of affinity partially purified fraction (Affinity), sephacryl separated fraction (sephacryl) and $(5 \mu \mathrm{l})$ protein marker $(\mathrm{M})$. Each well contained $\sim 30 \mu \mathrm{g}$ sample.

Fig 6: Truncated $\mathrm{N}$-terminal amino acid sequence alignment of lens $\beta A 2$-crystallin of Uromastix hardwickii (U. hardwickii) with known $\beta A 2$-crystallin of Anolis carolinensis (Ac), Columba livia (Cl), Iguanu iguana (Ii), D.mawsoni (Dm) and Oryzias latipes (Ol).

Fig 7: Expression of LDH mRNA in lens and liver of Uromastix hardwickii. mRNA expression level was analyzed by RT-PCR. cDNA was used as RT product with specific primers to amplify lens $L D H$ gene. L: Ladder; PCR-B: PCR blank; $L D H$ Lens: lactate dehydrogenase gene expression in lens; $L D H$ Liver: lactate dehydrogenase gene expression in liver. 
Fig 8: $5^{`}-3^{\prime}$ nucleotide sequences and translated amino acids sequence of amplified PCR product of $\varepsilon$-crystallin/LDH gene.

Fig 9: Nucleotide sequence alignment of lens $\varepsilon$-crystallin/LDH of Uromastix hardwickii (U.h) with known LDH of Iguanu iguana and S. undulatus by CLUSTALW. $\left({ }^{*}\right)$ shows matches and (.) show mismatches of nucleotides. 


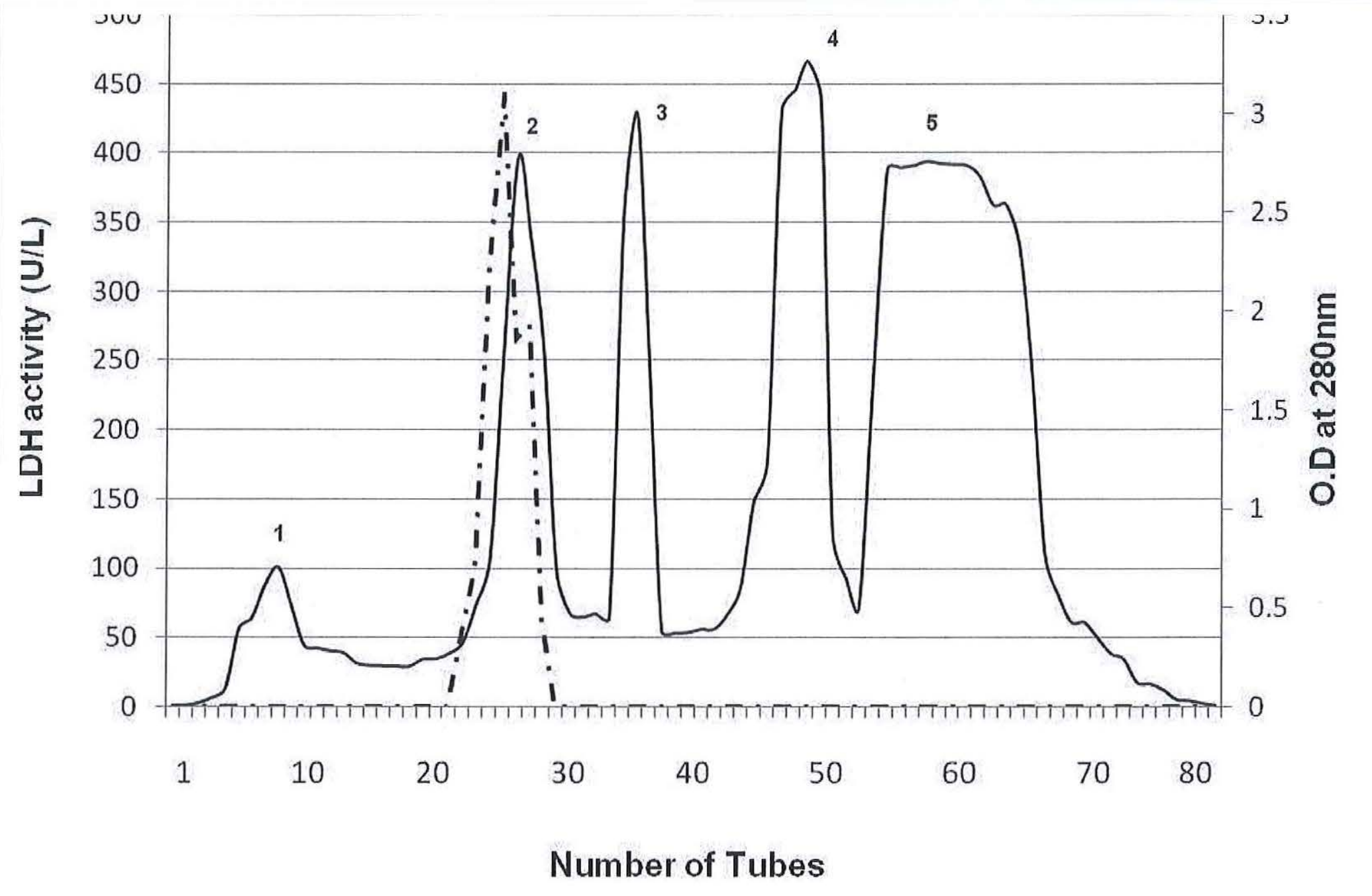

Fig- I 


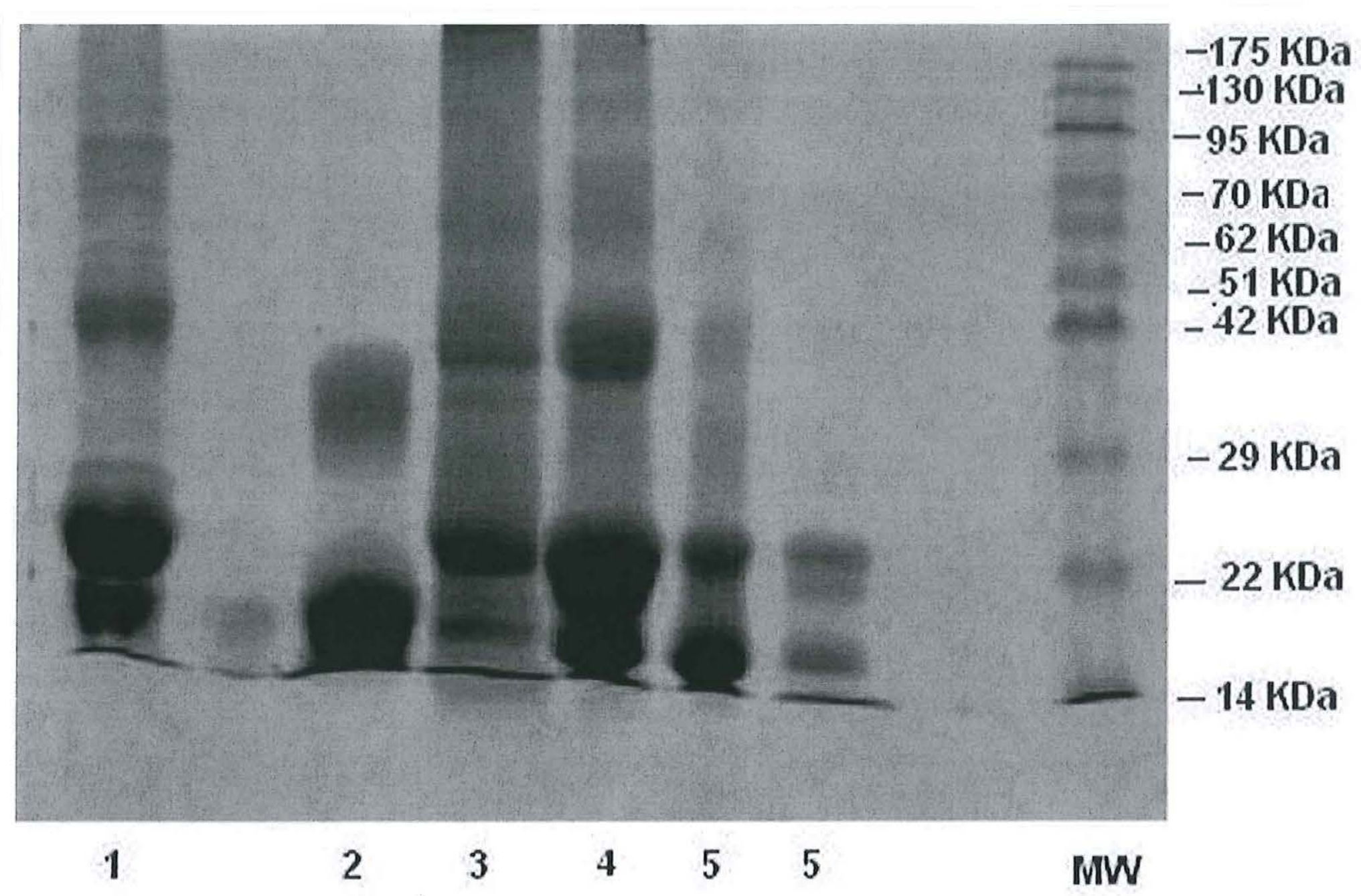




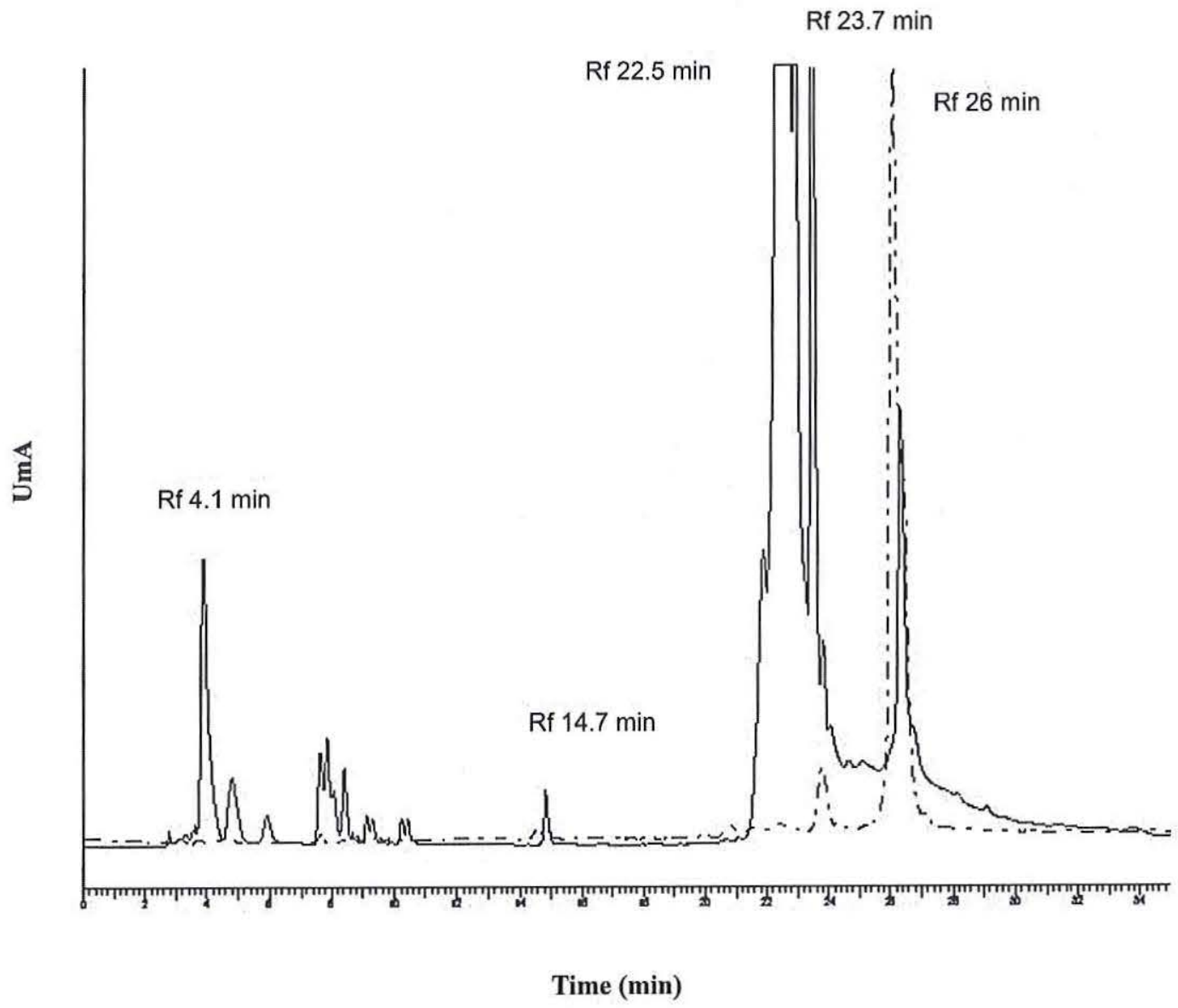



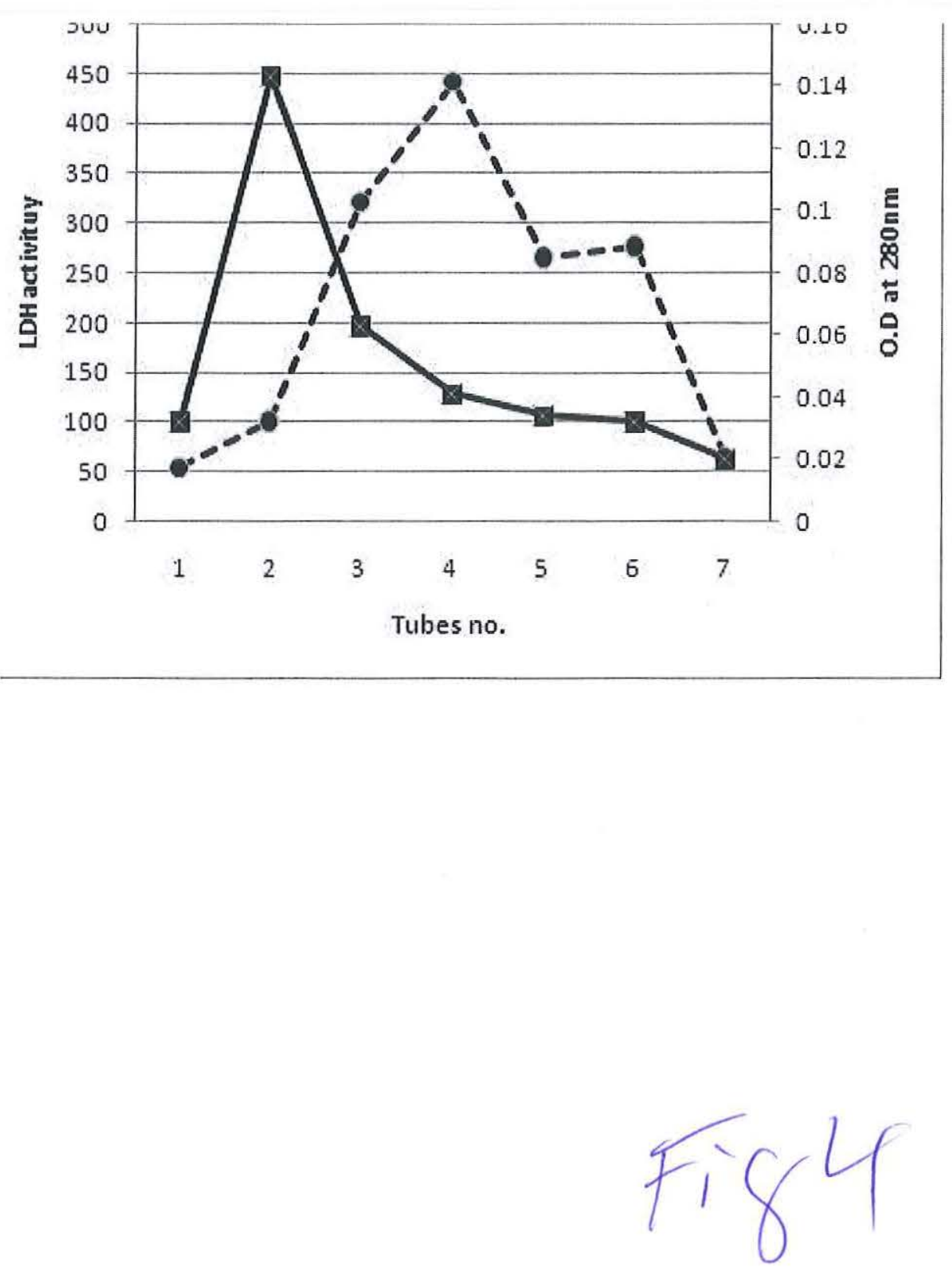
- $51 \mathrm{KDa}$

- $42 \mathrm{KDa}$

- $29 \mathrm{KDa}$

$-22 \mathrm{KDa}$

$-14 \mathrm{KDa}$ 
U. hardwickii

Ac

$\mathrm{Cl}$

Ii

Dm

OI
---SQFKI TVWE

-TLGQYKI TVWE

-TLGQYKI TVWE

-TLGQFKI TVWE

EQMGQFKI TVWE

-MQGQFRI TVWE

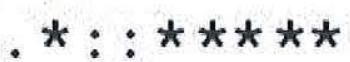

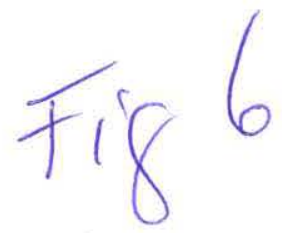


500bp

200 bp

$100 \mathrm{bp}$

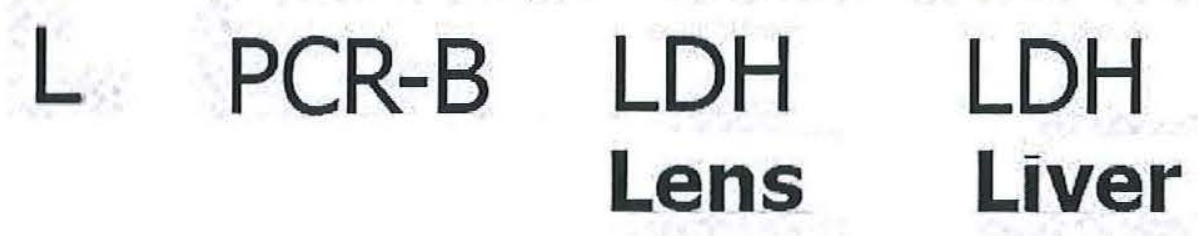

Fis 7 
ctgaagggctacaccaactgggccattggcttaaggtgtgggctg $\begin{array}{lllllllllllllll}I & K & G & Y & T & N & W & A & I & G & L & R & C & G & L\end{array}$ atttgcttggaggaggcggcagttttgcgtggaggggagggcgct $\begin{array}{lllllllllllllll}I & C & L & E & E & A & A & V & I & R & G & G & E & G & A\end{array}$ tttgcggacagaggatggcggttttcggg $\begin{array}{llllllllll}F & A & D & R & G & W & R & F & S\end{array}$

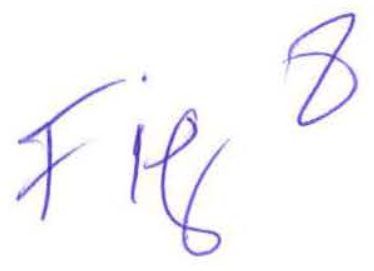


I.iguana

S.undulatus

u.h

I. iguana

S.undulatus

u.h

I. iguana

S.undulatus

u.h
СTGAAAGGCTATACCAACTGGGCCATTGGCTTAAG-TGTTG-CTGAACTGCTAAAAACCA CTGAAAGGCTATACCAACTGGGCCATTGGCTTAAG-TGTTG-CTGACCTGCTAGAAACCA CTGAAGGGCTACACCAACTGGGCCATTGGCTTAAGGTGTGGGCTGATTTGCTTGGAG--$* * * * * . * * * * * \quad * * * * * * * * * * * * * * * * * * * * * * * \quad * * * * * * * * \quad * * * *$...*.

TCATGAAGAACCTTTGCCGAATTCATCCAGTATCCACCATGGTCAAGGGGATGTATGGCA TAATGAAGAACCTTTGCCGAGTTCATCCAGTATCCACCATGGTCAAGGGCATGTATGGCA -GAGGCGGCAGTTTTG-CGTGGAGGGGAGGGCGCTTTTGCGGACAGAGG-ATGGCGGTTT **..*.* $\star \star \star \star \quad \star *:$ : . * . * : $* *: * * \ldots * * * *$.

TTGA-

TTGAA

TCGGG

**. 